C 52

個の場合により，また焼結の進行により大きく変化す るものであるのに一定としていること. 第二に活性化 エネルギーを構造に関係なく一定として理論を進めて いること・第三にアレニウス式が適用されるために は，反応につき問題としている原子，イオンが反応に 対してェネルギー以外の点で機会均等であり, エネル ギーがマックスウエル・ボルツマン分布によっていな ければならないが，実際はうク口粒子，マクロ粒子の 構造配列とも特異的で各原子イオンが均等ではあり得 ないし, 表面エネルギーの存在だけからも内部粒子と

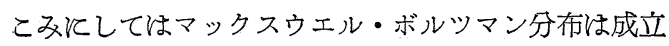
しない。

以上のように比較的簡単な焼結反応に秢いてさえ， 従来の速度論は不適格であり，もっと構造論を取入れ た形にしなければならない。

合成反応速度の場合子同様のことがいえるのであっ て，従来のように，まりきたりの奏験方法を用い，た だ漫然とアレニウム式により解析していたのでは，そ の人がその時, その方法で行った，その 1 回の害験に だけ固有な数值は求まるか子知れないが，普遍的な定 数は求めることはできない。またそれを普遍的な定数 のようと誤解するととほ，大きな弊害を伴うるのであ る.

以上, 焼結現象の解析から進えで, 固体反応速度の 従来の考方方に対し, 破䏅的な言辞をろうしてしま。 たが, 要するに, 構造論, 平衡論, 速度論のバランス のとれて実際の現象を説明できて応用性のある理論を 望もすのである・とのためには焼結現象にしても合成 反応にしても，粒子括よび配列の構造の比較的明きら かな状態で，特に必要なことほ温度伀達の速度の影響 のない実験を行い，以上の諸点に留意した解析を進め なければならない。

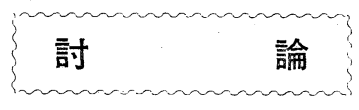

$\begin{array}{llll}\text { 司会者 } & \text { 東京工業大学 } & \text { 森谷 太郎 } \\ \text { 招待者 } & \text { 東京大学工学部 } & \text { 米田 幸夫 } \\ & \text { 千 葉 大 学 橋本 栄久 } \\ & \text { 東京学芸大学 河口 武夫 } \\ & \text { 東京工業大学 谷口 雅夫 } \\ & \text { 東京工業大学 伊藤 } & \text { 四郎 }\end{array}$

第 2 日の討論は講師の都合によって@固体表面の諸 性質と固体反応速度(2)金属粉末の焼結現象(3)烓結現象 の解析(4)一般討論の 4 回飞分けて行った. 編集の都合 で一括して発表いたします。亜しからず御諒承下さ a. (托)
窒協 65 [734] 1957 (2) 4

\section{「固体表面の諸性質」・「固体反 応速度」に対する討論}

森 谷 久保, 小松両氏の講演飞対して, 御意見ま たは補足ず゙き点があったら，特話し頂きたい、はじ めに久保さんの固体表面の問題について御発言初がい たい。

河 口 結晶粒子を粉硭してゆくと微結晶状態が変 わって, そのためX線と熱分析で追跡すると, 石英の 変態変化が括こると云われたが，この変化ね Dislocation 辸， あるいは，るっとミクロな格子 欠陷に基づくものなのか。またほ結晶成長と表面エネ ルギーの問題で, 新しい表面ができたとき, その表面 エネルギーは大きいが，この面にさらに結晶が成長し てゆくのか, あるいは他の面住生じるのか. 表面エネ ルギーが大きければ結晶性じやすいだろらが，これ と Dislocationと，ぞのような関係にあるのか。ある

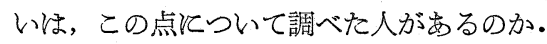

久 保 表面層のことは金属の方で, ベイルビー層 として研究されているが, ベイルビー層は, はじめは 非晶質と考えられていたのが，X線でなにも出てこな くても，結晶の大きさが小さな場合にほ，そのような ことがありうる。とれで最近では微結晶と考えるよう になってきている・けっきょく, 石英の Low-high inversion をやり るる結晶性の部分が, 微粉の程度が すすむとしたがって少くなってゆく、これを熱分析と X線で定量的にやったのだが, Inversion しない表面 層の構造がぞうなっているか見当がつかない。まあ表 面に無定形のもの，または Microcrystal のようなる のができていれば，その中に別個の物質を吸着させ て, 普通の電子顕微鏡で, 内部と区別することができ ないであろらか.また制限視野の電子迴析で見れば, 方向性を持った結晶が区別できると特る5。

また，第二の点については，はじめ表面エネルギ 一の小さな面が出てくることは十分考えられる・しか し結晶をつくるときの, いろいろの条件で, 結晶の成 長の様子がかわるであろう，この点については, 融液 から雲母を生ずる時の経験があると思うので石川さん に，それを伺いたい。

石川 雲母については, 高温度でやっていること なので，よく判らない、結晶を大きくすることに努力 しているが，説明できるような材料がない。

山口 変形層の梁さが 0.3 ミロンくらいという ことだが，電子回折で出した“d”とX線で出した “d”に，なにか差が出てくると思うが，出した例はな いか。

久 保まだやっていないと思う. 0.3 そクロンの 表面層があれば，原子番号が大きく，原子容の小さな 
重金属でも沈着させれば, 電子顕微鏡を使って, 表面 首と內部とを区別できるだろうと思う。

山口 京電子顕微鏡で, ぞのくらいのるのまで 透視でみられるようとなっているか。

久 保 石英などでは長薄切片をつくらなくてはな らないから大変だが，超高圧を使った電子顕微鏡で内 部構造をみた方がよくないか.30 万ボルトだと, 薄 片が数枚かさなったものほ無理だが，薄い部分だと透 過する。

米田 表面の変形層は,アルミナなどでは酸素の 同位元素で表面の酸素と, 気相その他で交換反応させ てみると $500 \sim 600^{\circ} \mathrm{C}$ で 1 2 層は交換する. しかし 変形層が 0.3 ミクロンくらい厚いとすると，逆にいう と，この変形層は拡散など飞影響しないのではない מ.

久 保 同位元素の実験てついては良く調べてない が，表面の変形居は，まだ確かなるのではない，実験 者も，旮れ活で深い根拋があって，云っているのでは ない。さしろ, 別個な方法でこれを研究しないと判ら ない。

河口 山口, 米田両氏の発言について, 久保さえ 核, 変形層の厚さを出すのに, 石英粒子を球形と仮定 し，その Low-high inversion を起こさなかった部 分の割合から算出したが，このような方法以外でもや ってみなくてはならないと思う。しかし，一体，この 変形層は永久的に変形しているのか, あるい数百度 の温度で安定形炕戾るものなのか, 皆さんに和うかが いしたい. Low-high inversion 飞よって変形層の厚 さを測っているが，安定なるのではないから，変㦔を 招こさせるための加熱收よって変質することる考兑ら れると思う。

森 谷 原理的にはとうだが，その与光られたエネ ルギーの大きさ，つまり加熱効果の正確な結果は実験 的見つるるととは困難なととだと和るう。

石川粉硭したときと，表面が破壊してしまうと いうことを経験したことがある・雲母を粉碎したとき

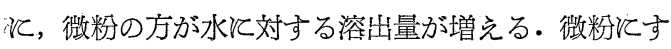
ると表面がこわれてしまうのではないかと思う。

久，保 変形層をるら一度加熱するとどうなるかと いう点では, 少し加熱すると結晶化が起こりやすくな ると思う・粉末を再加熱して䔝鈍する場合にる，新し く, 表面エネルギーの低いものができてくる。一方で は，内部の正常な格子があるのだから，杂れ接して いる無定形の部分が結晶化を起すような外的条件にさ らされた場合とは，内部の結晶の性格を持った結晶に :変化するのではないかと考光る。

森 谷 固体反応のとき, 粒子の表面の不安定さと 心うものの効果が反応速度に影響があると思うが。
小 松 表面の状態は反応速度に影響はあると思う が，そのような報告はあまりない。しかし，シリカな

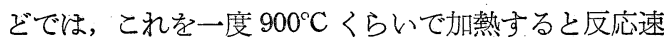
度が低くなる・また炭酸バリウムとシリカの混合物次 ついても，このようなことが起ることる確かである。 しかし表面の状態が加熱効果で変わるということは確

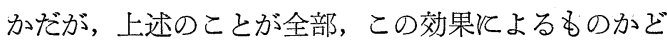
らか判からない。

鈴 木(東工大) 拡散係数, $D_{A}, D_{B}$ 恃間飞対し て常数としてあつかったのか。

小松そうです。

鈴 木(東工大) これが時間ととすと変化すること はないのか：

小 松 生成風の構造が変っても拡散係数や活性化 エネルギーと変化がないと仮定している。

鈴 木(東工大) 実験結果が式合ったということ は, 拡散係数も活性化エネルギーる，時間にたいして 不変と考克てよいということか。

小松そこ末でいうのほ，行過である.

鈴 木(東工大) 金属の錆反応なぞでは，途中で酸 化の機構が変わると考光て, 拡散係数が時間的飞変化 するような式が提出されているが，このような場合と 中間層がだんだんと焼結するとか，焉すいは内部から 過少成分が拡散してきて中間層の穴が詰って，拡散係 数が変わるというような問題とついて考光たことはな いか。

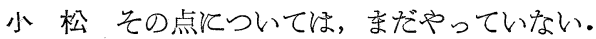

鈴 木(東工大) このような問題をやっている人が， あったら教光て頂きたい。

森 谷 あまりないのではないか。

境 野 $\mathrm{A}-\mathrm{B}$ 成分の比を横軸飞し, 反応速度を縦 軸としたグラフで，中間に極小点が現われているが， これは A， B 両成分が相互拡散をするという仮定を入 れたためと現われたものか，入れなくても現われるも のか.

小 松 便宜的々は相互拡散を仮定しないと, 拡散 エネルギーが非常に違った場合飞相当して極小点がで てこない。過少成分の掋散が律速段階であるときは,

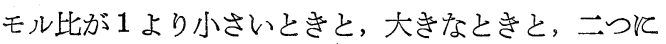
分けて，両者の匂配の交わるところ極小が現われる と考劣てもよい。はじめから単純な拡散のみを考光る と，一般論としては極小点はでてとないと思う。

境 野たと光ば，A，B 両成分の粒径が，ほぼ等 しい場合の混合について, 両者の接触点の数を考兄る

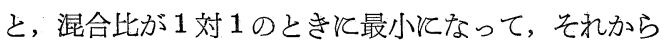
ずれるにしたがって次第に大きくなり, ある一定值に 近づくと考光られる，したがって，この両者の接触点 の数が反応速度の大きな因子と考えるならば，拡散が 
相互的であるとか，一方的であるとかいうことと無関 係極小点が現われてよいのではないか。

小松 大体，中間で反応速度が下がるということ は，そういうことからるい光るが，や梳散係数が 入っててないと、はっきりと任い光ないのではない か.

境 野 また相互拡散とついてであるが， A，B 両 成分の間に中間層ができたと考光て, どちらの成分 が，どちらへ向って拡散しているかということが一義

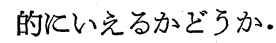

小松 それは見かけの問題で，でちらともい党な

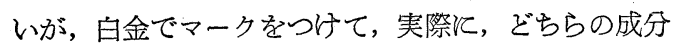
が動くかを確かめた実験はある。

境 野 乙かし, A,B 両成分の間の中間首の中に は, $\mathrm{A}$ 成分の濃度包配る, B成分の濃度匂配も存在し て㧍り, 小松さんの場合でる, 中間層の内部で両成分 の濃度匂配に不連続点を考学ていないとすれば，一方 拡散も相互拡散も本質的には区別できないのだから， それとよって反応機構に差を生じるとは考光られない のではないか。

小 松 厳密に区別するということでなく，一方だ けが拡散するということが，事実洽っていないとい うことである。

森 谷 いまの二人の討論について，なとか他に意 見はないか・な扮意見が後にあったならば講演者あて に出して頂きたい．これ対する回答は空業協会の方 へ出して頂きたい.

\section{「金属粉末の焼結現象」に対する討論}

森 谷 ただいまの講演について討論るがいたい。

杉本フェライトなどの金属酸化物が焼結してゆ くときに，ぞんな力で粒子がくっついてゆくのか，末 た，その焼結の機構はどういうるのであるか. 金属酸 化物の場合主金属自体の焼結と大分違らと思うが。

鈴 木(東大) 金属単体の場合でも焼結機構は十分 判ってない現状であり, 従って酸化物の場合であれ ば，ぞの程度金属と共通性があるか即答しかねる。

森 谷フェライトの焼結について，ぞなたか意見 はないか。

杉 本 ベンガラ (フェライト) 飞は立方体のもの があるが，これを焼結させると完全注固体になって しまうが，なぜ，そなるのうか，機構が知りたい。

鈴 木（東大）自分のやっているのは金属だし， 酸化物を扱ったことがないので判りかねる。

森 谷 酸化物の焼結の機構はむずかしく, 酸化物 の焼結の機構とついて研究はされているが, まだ,は っきりした結論が得られていない，今日のシンポジウ ムも，そのような機構を少しでも知り，知見をひろめ

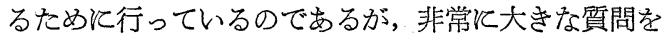
投げかけられた訳である。すう少し，限定した事柄に ついて意見はないか。 また金属の焼結と酸化物の焼結 の大きな差は，ぞこ㐫るのか. 久保さ九，ひとつ.

久 保 ごく常識的なことしか話せないが，酸化物 と金属の差は一逆滛酸化物と金属を焼結させるとき には，そのま季では原子間の結合の形式が違うから着 かない、それで，たと壳ば，ガラスに銀メッキするよ らなときには, 錫の化合物の溶液に浸したりして, 錫 の化合物を仲介飞使い，これがガラスの方に対して は, イオン的にくっつき, 反対側の方には金属原子の ような性質を示してくっつく.このようとすれば，銀

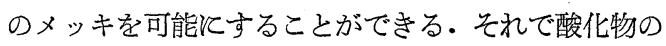
方の焼結はイオン的な性質飞基づき，金属の方は金属 結合飞基づいているといらょうと考兄られる。

森 谷 結合の性質が違うと焼結の機構が違うとい 万久保さんの意見であるが，鈴木さんの括話で金属の 焼結の問題が大変よく判った。金属の方面など案業と 違った立場松られる方の招話をうかがうことのでき たことは幸であった。

\section{「焼結現象の解析」対する討論}

河口烍結も熱力学的な立場からかんが壳れば， 室温でる100\% 進行しなければならないと云われた が，100\% の燌結とはどんな意味であるか。

山 口格子欠陷などは無視して定性的な云い方を すれば, 気孔の少い磁器質のようなるのを考克てい る.

河口すると肉眼で識別できる程度をいうのか.

山口違う。それを，さらと温度を上げれば，さ らに焼結する。ミクロ粒子を考光れば，その間隔は原 子間の間隙の数倍ないし数十倍は離れているである う・この程度ならば燒結することができる。

河口たと党ば，無定形のものと加熱または他の 操作を与兄てやれば，再結晶が起ることは考学られる か.

山口いままでの固体反応では，用いる原料粘子 のミクロの構造が明らかとされていなかった。それ で,このような構造をはっきりさせて，解析しなけれ げ正しくないと考党ている.

河 ロマクスウェル・ボルツマンの分布則が正当 性のない場合飞, 活性化エネルギーの意味はどういう るのか。

山 口定性的にしか考兄ていないし，まだ報交と して出してはいない。

小松ミクロ粒子の焼結で, 粒子が離れていて, 焼結が始まるためとは，なとか動かなくていならな い.このとき，分子のようなるのが，た卡 1 個飛えで 
ゆくのか，あるいは，いくつか集団で動くのか。

山口純粋系の焼結でほ, 第 3 物質が関連してい ることが多いと思う．表面の活性の大きな原子や分子 の振動による相互の接近などが大きなチャンスになる と思う。

小 松 同時に, いくつかの原子が動くのでなけれ ば見かけの上で焼結というようなものは起らないので はないか。すると同時現象であるからエネルギーの分 布のフチがもっと上ってくると思う。

山口 ミクロ焼結の方は温度によってきまってし まう段階が顕著である。

境 野 焼結の完結した状態, つまり 100\% 焼結し たという状態を，どのようと考えているか。

山口 $100 \%$ 焼結というのは抽象的な考光である が，具象的に考觉れば，平衡論的に云っても，表面積 が最小，つまり球状になると思う。そして気泡すまっ たくなくなった状態である・

森 谷 焼結の目安が，はっきりしていない。これ が、はっきりしなければ意味がない。ある温度で長時

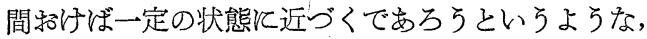
平衡状態に達すれば，100\% 焼結と考えられたのだと 思う。

山口ここで云らた 100\% 焼結というのは最終段 階のことで, 理論的には表面積が最小になったときの ことを考えている。

\section{一 般 討 論}

森 谷 最後に, ぞの講演飞ついてと限定しない でまだ時間が少しあるので，意見なり討論があった ら，和願いしたい。

鈴 木（東工大）金属の焼結の講演中にあった Fig. 9 や Fig. 11 のモデルは大体 Polycrystalと考 光てよいか.

鈴 木(東大)要理想的飞は球状の粉体と考光, その 内部は微結晶からなっていると考えている。

鈴 木(東工大) アルミナなどでは，焼結によっ て，徐々に六角形が見えてきたりすることがあるのだ が，金属の方で㤬焼結の際に，微結晶の成長という現 象は，山まりないのか，

鈴 木(東大) やほり Grain growth はする.乙か し, 粉末の内部の Grain が大きくなっても，とのま までは気孔はへらなから，このことは，焼結の進行
そたいして，ままり影響しない。

阿 部(信越化学) 炭酸カルシウムと酸化モリブデ ンの固体反応の場合に，相互拡散を考兵ると，4種の イオンが移動すると考えなければならないが，これは さずかしいことではないか。

小松とのことについては，また発表していな い.しかし，Wagner 流のかんがえ方には満足してい ない. Hedval などのものをみると，かならずしも移 動するものがイオンである必要はないと思う。

河口 金属の焼結の場合に，気孔がなくなると焼 結が終ると云われたが，C 43 ページ，Table 2 をみ ると，焼結が進むにしたがって，大きな気孔が増えて いる. Micro-pore と Macro-pore の境界は 5 ミクロ ンくらいと思ったが，金属の焼結の場合にも，なんら かの規準があるのか。

：鈴 木(東大) 正確な分類はない，要するに全体と しての気孔が減少すればよいと思う。

河口気孔の大きさを分類しないと, 焼結の進行 を現わすととができないのではないか.Anderson の 場合には，Micro-pore と Macro-pore とに分け，そ の容積で進行を表現している.

鈴 木(東大) 焼結の状態は，時間と温度とが大き くなるほど，気孔率は小さくなるだろらが，焼結材の 密度増加が大切であり，気孔のなくなるメカニズムが 重要なのである。たとえば，Table 2 のように，時間 とともに，小さい気孔がへり，大きな気孔が増觉てゆ く・このようなメカニズムを明らかにするために、こ の実験が行われたのだと思う。

川口大きな気孔の表面にある Vacancy が小さ くて，小さな気孔のそれは大きいというのは，事実 力.

鈴 木(東大) Vacancy の大小とはとの密度のこ とであり，そういう考えに基づいてRhines 達は実験 結果の説明を行っている・

森 谷まだまだ問題はあるが，時間がないので， のちほで十分討論して頂いて，その結果を協会の方へ しらせていただければ幸いである。

長時間, 御協力頂いて，ありがない。とくに，窯業 関係以外の方々飞参加して頂いて，粉体や，その組 識，括よび，その焼結などについて貴重な話をうかが い，討論できたことを感謝している。では，これで閔 会にします。.

八木一夫・河合 紀 作陶展 来る 2 月 18 日から 23 日までの 6 日間にわたり東京都中央区銀座 西 5 丁目の養精堂ギャラリ一で開かれます。銀座方面に秥出かけの節は拉立ち寄りの上ごらん下さい。 